\title{
ASSESSMENT OF THE LARGE MAMMALS OF ARAKHUAN RANGE, OKOMU NATIONAL PARK, NIGERIA
}

\author{
Akinsorotan, 0. A., * Ogunjemite, B. G. and Afolayan, T. A. \\ DOI:http://dx.doi.org/10.4314/ejesm.v4i3.4
}

Received September $26^{\text {th }} 2011$; accepted October $5^{\text {th }} 2011$

\begin{abstract}
An assessment of the large mammals of Arakhuan Range, Okomu National Park, Edo State, Nigeria, was carried out using land transect methods. A total of 12 large mammalian species were observed (eight directly and four by their signs). These are made up of four primate species; Red-capped mangabey (Cercocebus torquatus), Mona monkey (Cercopithecus mona), White-throated monkey (C. erythrogaster pocoki), and Putty-nosed monkey (C. nictitans ludio), three species of antelope: Maxwell duiker (Cephalophus maxwelli), Yellow-backed duiker (Cephalophus silvicultor), and Red-flanked duiker (Cephalophus rufilatus), and a species of mangoose (Herpestes sp). Those observed through their activities were forest elephants (Loxodonta africana cylotis), forest buffalo (Syncerus caffer nanus), civet cat (Viverra civetta) and the red river hog (Patamochoerus porcus). Altogether, 145 sightings of animals were recorded during the study period. Mona monkeys were most commonly sighted (sighted 37 times, producing 0.22 sighting/ $/ \mathrm{km}$ ). The Red-flanked duiker was the most abundant with an estimated density of $36.66 \pm 7.68 \mathrm{~km}^{-2}$ and population of $1970.93 \pm 412.93$ individuals. The yellow-backed duiker was very rare in the range as it was sighted three times with an estimated population of $9 \pm 2$ individuals. There is very strong correlation between sightings in the morning and that of evening $(r=0.94, P<0.05)$. However, there were significant differences in sighting on transects $\left(\chi^{2}\right.$ cal. $=35.18, \chi^{2}$ tab. $\left.=32.7, d f=10, P<0.05\right)$ indicating that sightings are transect-dependent. Over $50 \%$ of all sightings were achieved in the matured forest.
\end{abstract}

Keywords: Mammals, line transect, sightings, estimated population.

\section{Introduction}

Large mammalian fauna of Africa are subject of serious concern to many interest groups (Mendoza and Palmqvist, 2006) because Africa contains the last great community of large mammals in the world (Eisennberg, 1990). However, attention had been focused largely on grassland communities most especially in the West African-Sub region (Afolayan et al, 1995; Dunn, 1999; Child, 2000; Akinyemi and Oduntan, 2004). There is limited information on the rainforest mammalian species beyond the primate communities (Agbelusi, 1994; Oates et al., 2008).

Information on large mammal distribution and abundance is very important to the understanding of their significance as ecological driving force and their development for tourism purposes. This information is also vital in evaluating conservation hotspots, eco- tourism potential for game viewing, the nature and extent of wildlife human conflicts and sustainable harvesting of bush meat by local communities (Newmark et al., 1994; Naughton Trevee, 1998). The threshold size criterion for large mammals had been variously put at $3-5 \mathrm{~kg}$ weight or about $50 \mathrm{~cm}$ height (Eisenberg, 1990; Emmons, 1990).

In Nigeria, a major problem facing wildlife conservation is the increasing rate of habitat loss or modification due to human activities (Ogunjemite et al., 2007). There is no doubt that there has been large-scale destruction and mismanagement of the forest ecosystems of Nigeria. Ecological disasters and climatic change have resulted in loss of soil fertility and greatly reduced biological productivity (Agbelusi et al., 1999). Afolayan et al. (2004) observed that about $75 \%$ of the original wildlife habitat in Nigeria had been lost. This has affected wildlife resources within these ecological systems leaving only remnant populations of wildlife resources in protected areas including the National Parks.

National Parks are relatively large area of land or sea where one or several ecosystem is not materially altered by human exploitation and occupation, where animal and plant species, geomophological sites and habitat are of special scientific, educative and

Department of Ecotourism and Wildlife Management, Federal University of Technology, Akure, Nigeria.

*Corresponding author email: ogunjemite@yahoo.com 
recreational interest or which contain a natural landscape of great beauty. Okomu National Park contains the relics of the primary rainforests of south western Nigeria eco zone and it is the major hope for the long-time survival of the remaining biological diversities of the region. Oduwaiye et al., (2002) observed that the park endowed with a complex assemblage of fauna and flora species. The park is one of the sites that offer an excellent opportunity for the realization of the Nation's tourism objectives. Okomu National park has one of the foremost tourist features that can interest potential tourist in south western Nigeria. Located within an easy proximity to many of the busy cities of the region, the park offers chances to attract influx of tourist from these locations for possibility of weekends in a serene rain forest environment. Arakhuan range of the park in particular offers a wide range of complementary destinations that can boost ecotourism of the park.

In Nigeria, ecotourism may prove a viable alternative to the sole dependence on petroleum resources for revenue. Ecotourism involves traveling to relatively undisturbed natural areas for educational, recreational, inspirational and scientific purposes. The purpose may be for studying nature in its pristine state, admiring a beautiful scenery, observing wild animals, plants and flowers or appreciating unique geological formation, geomophological or cultural sites there in. Marguba (1996) observed that ecotourism involves traveling to National Parks and other nature reserves for relaxation, solitude or meditation.

Large-bodied mammals are easy to sight in rain forest environments and are therefore one of the first attraction to tourists. These include the non-human primates whose close resemblance to human confers on them special interest from tourists. Their daily activities provide humans with the ability to prone into the primitive age of man. There is a need to assess the distribution and population of these animals for their proper management for tourism development. The conservation and management of these animal populations require a reliable knowledge of the population status in an area (Mandujano and Gallina, 1995). This study was designed to assess the distribution and abundance of large mammals of Arakhuan Range, Okomu National Park in order to develop them for management of ecotourism in the park. The objectives of the study are therefore as follows; (i) to determine the distribution and species composition of large mammals of Arakhuan range that can aid the development of ecotourism in Okomu National Park, (ii) to determine the sightings and sighting rates of these animals in the range, and (iii) to provide an estimate of density and abundance of the large mammals in the range.

\section{Materials and Method \\ Study area}

Okomu Naional Park covers a total area of 181 $\mathrm{km}^{2}$, which is only $15 \%$ of the $1200 \mathrm{~km}^{2}$ area covered by the Okomu Forest Reserve. It is situated between longitude $5^{\circ}$ and $5^{\circ} 30^{\prime}$ east and between latitude $6^{\circ} 10^{\prime}$ and $6^{\circ}$ north Park (Fig. 1). It was originally gazetted as a wildlife sanctuary by the Bendel State Government in 1986 through legal notice number 198 of 1986. It is located in Ovia Southwest Local Government Area of Edo State. This conservation enclave became a full fledged National Park in 1999 through the promulgation of Decree 46 of 1999 . The park lies $45 \mathrm{~km}$ west of Benin-City and immediate south of Udo town. It derives its name from River Okomu which flows southwest to join the Osse River. The rainfall in the area is well above $2500 \mathrm{~mm}$ per annum. The area is within 300 meters above sea level. Ikhuoria (1993) described the soil in this area to be ferrallitic, composed of quartzite and kaolin from tertiary secondary sedimentary rocks. Okomu National Park lies within the humid lowland rainforest zone of Nigeria (Orhierre, 1992). Tree species found in the park include Millicea excelsa, Triplochiton scleroxylon, Nauclea diderichii, Terminalia species and Ceiba pentandra.

\section{Data Collection}

A total of $13.9 \mathrm{~km}$ transects $(\mathrm{A}=3.3 \mathrm{~km}, \mathrm{~B}=3.0 \mathrm{~km}$, $\mathrm{C}=4.0 \mathrm{~km}$ and $\mathrm{D} 3.6 \mathrm{~km}$ ) length were selected from about $32.6 \mathrm{~km}$ of the existing tracks and trails in Arakhuan range of the park based on the recommendation of the American Sub-committee on conservation of natural populations (1981). Enumerations were carried out as described by Agbelusi et al. (2003). Enumeration lasted daily from $6.30-1130 \mathrm{hrs}$ and from $15-18 \mathrm{hrs}$. 
Enumerators (Researcher, Research Assistant and a Park guild) walked quietly and slowly along the trails at a rate of about $1.0 \mathrm{~km}$ per hour. Standardized data sheets which contain information about the species, numbers of individuals observed, habitat types, location, date, starting time and weather. When any animal or groups of animals were sighted, a standard time of ten minutes was spent observing and taking records of their activities. At each sighting, the GPS coordinate was taken along side the information using the Garmin 72 XL.

Habitat types were defined in three ways following Tutins and Fernandez, (1984).

\section{Data analyses}

Analytical tools employed include frequency count and percentage. The student t-test analysis was used to compare sightings in the morning and evening surveys while the $\chi^{2}$ analysis was used to compare sightings on transects using the Microsoft Excel software 2003.

Density was calculated using the formula:

$$
\text { Density }=\frac{N}{A}
$$

\section{Equation 1}

Where $\mathrm{N}=$ total number of animals estimated

$$
\mathrm{A}=\text { total area }
$$

Population is given by

$$
\text { Population }=\frac{A Z}{2 X Y}
$$

\section{Equation 2}

Where $\mathrm{P}=$ population of area censured

$\mathrm{A}=$ total area

$\mathrm{Z}=$ number of animals seen (each species

treated separately)

$\mathrm{X}=$ mean sighting or perpendicular distance

$\mathrm{Y}=$ length of census line (transects)

\section{Results \\ Species composition}

Table 1 shows the different species of large mammals that were directly censured in this study, while plates $1-3$ show the photographs of some of the animals sighted; comprising four primate species (Red-capped mangabey, Mona monkey, Whitethroated monkey and Putty-nosed monkey), three species of antelope (Maxwell duiker, Yellow-backed duiker, and Red-flanked duiker) and a species of mangoose.

\section{Sightings}

Table 2 presents the general trends in sightings of large mammals of Arakhuan range Okomu National Park. A total of 145 sightings were recorded in the 12 censuses carried out within the study period. The mona monkey was the most commonly sighted (sighted 37 times, producing 0.22 sighting $/ \mathrm{km}$ ). The red-flanked duiker was the second most sighted (28 sightings, producing 0.17 sightings $/ \mathrm{km}$ ), followed by Maxwell duiker (25 sightings, producing 0.15 sightings $/ \mathrm{km})$. Other sightings include White-throated monkey (18 sightings, producing 0.11 sighting $/ \mathrm{km}$, red-capped mangabey (16 sightings, producing 0.10 sighting $/ \mathrm{km}$, Kucusimance mangoose (15 sightings, producing 0.09 sighting $/ \mathrm{km}$ ), Putty-nosed monkey (4 sightings, producing 0.02 sighting/ $\mathrm{km}$ ) and Yellow backed duiker (3 sightings producing 0.02 sighting $/ \mathrm{km}$ ). Sightings in the mornings were significantly different from those of the evenings $(\mathrm{P}<0.05, \mathrm{r}=0.94)$ and there was very strong correlation between the two periods.

\section{Distribution}

Table 3 reveals the specific trend on the distribution of the animals on each transect used in this survey. About $54.48 \%$ of all the sightings made were recorded on transect A (Table 3). All the animal species directly sighted except the yellow-backed duiker were recorded on the transect; while 24 sightings, representing $16.55 \%$ of all the sightings were recorded on transect $\mathrm{B}$, comprising of only five out of the eight species recorded for the range. On transect C 32 sightings, representing $22.07 \%$ of all the sightings was recorded where all the species were also recorded except red-capped mangabey. Only ten sightings $(6.9 \%)$ were recorded on transect $\mathrm{D}$, comprising of only three species of the animals directly observed in the range. There were significant differences in sightings on transects $\left(\chi^{2}\right.$ cal. $=35.18$, $\chi^{2}$ tab. $\left.=32.7\right)$.

\section{Population Estimates}

An estimate of the population of animals within Arakhuan range is presented on Table 4. The mona monkey had the density of $4.47 \pm 1.24$ troops $/ \mathrm{km}$ with an estimated $240.18 \pm 66.49$ troops in the range. This translates to an estimated 1441.05 398.96 individual within the range. 
This was followed by the white throated monkey with an estimated density of $2.66 \pm 1.52$ troops $/ \mathrm{km}$, giving an estimated $142.93 \pm 81.55$ troops within the range. This translates to an estimated 856.2 \pm 489.45 individuals within the range. The red-capped mangabey had a density of $2.15 \pm 0.88$ troops $/ \mathrm{km}$ with an estimated $115.7 \pm 47.36$ troops in the range. This translates to an estimated $347.3 \pm 142.29$ individuals within the range. The putty-nosed monkey recorded the density of $2.40 \pm 1.50$ troops $/ \mathrm{km}$ with an estimated $20.7 \pm 12.08$ troops in the range. This translates to an estimated $128.84 \pm 81.49$ individuals.

The red-flanked duiker was the most numerous of the antelopes having a density of $36.66 \pm 7.68 / \mathrm{km}$ and an estimated population of about 1970.93 \pm 412.93. This was followed by Maxwell duiker with a density of $20.54 \pm 5.44 / \mathrm{km}$ and an estimated population of $1104 \pm 292.65$. Among the antelopes the yellow-backed duiker had the density of $0.17 \pm$ $0.36 / \mathrm{km}$ with an estimated $9 \pm 2$ individuals. The Kucusimance mangoose had an estimated density of $8.16 \pm 3.96 / \mathrm{km}$ with an estimated population of $438 \pm$ 212.64 individuals in the range.

\section{Other Large Mammals Observed}

Four other large mammals (elephant, bush pig, civet cat, and forest buffalo) were observed indirectly by their signs and through opportunist sightings (Table 5). Lots of elephant activities were observed on all transects used except transect B. Two opportunist sightings of bush pigs were recorded towards the end of transect A around the "old tree house". The distributions of the animals are shown in Figure 5 while plates $4-7$ show some of the activities of the animals sighted.

\section{Discussion}

Arakhuan range of Okomu National Park, Edo State, Nigeria still maintains one of the highest concentrations of the large mammalian fauna of south western Nigeria. Of the 12 large mammals observed in the range, eight were directly observed in this study; three were recorded by their activities and one through opportunistic sightings and its activities. These species of large mammals are similar to those of other forests in southwestern Nigeria such as Ifon
Game Reserve (Agbelusi and Afolayan, 1991; Omo Forest Reserve (Onadeko, 2004); Omo-OluwaShasha Forest Complex (Oates et al., 2008, NCF, 2008). Agbelusi et al. (2003) reported eight species of primates in the park in which three were nocturnal animals. Four of the species reported were directly observed in this study with the exception of the chimpanzee. Their methods include interview and searching through the forest for animal signs while the methods in this study were limited to sightings from transect lines.

Animal sightings are generally poor in rain forest environment and the situation in Arakhuan range of Okomu is not exceptional. However encounter rate (sightings $/ \mathrm{km}$ ) in the range seems to be one of the highest recorded for monkeys in Nigeria. Recorded value of 0.22 sightings $\mathrm{Km}^{-1}$ in Mona monkeys translate to one sighting in about $4.5 \mathrm{~km}$, is higher than an average of $0.14 \mathrm{Km}^{-1}$ in Filinga Range (core area) of Gashaka- Gumti National Park (Gawaisa, 2006) a park reputed to be the primate paradise of Nigeria (Sommer, 2004), and $0.1 \mathrm{Km}^{-1}$ of the Okwangwo Division of Cross River National Park (ODA/WWF/CEC, 1990).

Encounter rates with animals appear generally high in the Arakhuan range of the park. The number and varieties of animals sighted are usually of special consideration for any ecotourism enterprise (Odewumi 2004). Tourists are attracted by the number of different species that could be sighted and the abundance of each of the varieties seen. Three of the arboreal monkeys (Mona, White throated guenon and red caped mangabey were commonly encountered and their troop sizes were seven, six and three respectively. These could be complimented by two additional widely distributed antelopes; the Maxwell's and Red flanked duikers. Transect A is located in the area where tourist facilities (chalets, offices, rangers post, catering facilities and recreational facilities) are built and human presence are constantly felt, thus mitigating the activities of poachers and giving animals and tourists within the range security. Transect-dependent sighting was vividly proved from the numbers of sighting achieved on transect A $(54.48 \%)$. The animals appeared acclimatized to human activities, less frightened and could be easily seen by intending tourists. 


\section{Distribution}

The animals in Arakhuan range are widely distributed especially the three commonly encountered monkeys and the antelopes; and transects $\mathrm{A}$ and $\mathrm{B}$ are of particular interest in this wise (Tables 3). Both transects recorded seven species of large mammals that were directly sighted and at least activities of two animals that are not directly sighted. The activities of arboreal primates and medium size antelopes are most often synchronized since both groups rely on the same food items, though at different strata. Transect D recorded the least number of animals in terms of diversity and abundance. However the transect recorded lots of activities of elephants and buffalos (Figure 5); it may be that the activities of these animals preclude the occurrence of the smaller animals in the area. The activity (foot prints) of a nocturnal animal; Civet cat was also recorded in the area. Arakhuan range is one of the most accessible areas of the park all the year round. Animals which are not known to be prominent in the range in the time past are now commonly encountered. For instant, the activities of forest elephant which were restricted to mile three range in the past (Menjo et.al 2007), are now observed severely in the range in this study. (Table 5, Plates 4 \& 5)

\section{Population}

The estimated population of animals within Arakhuan Range seems to be high for most of the encountered mammals except for the yellow backed duiker. This could be attributed to the fact that the animals were not often harassed and were thus not threatened in the range. Arakhuan range is about 54 $\mathrm{km}^{2}$ and approximately about $25 \%$ of the total park area. Many of the animals in other parts of the park may have moved to this range in the recent time for the fact that this portion of the park seems to be the most secured (Koyenikan 2004, Greengrass, 2006). There appears to be an upsurge in the numbers and the activities of animals in the range over previous works (Oates 1995; Agbelusi et al., 2003; Koyenikan 2004), however the high densities and number of animals in the range could not be generalized over the entire park, since poaching activities are always reported from the southern and western parts of the park where the Niger-Delta militant activities are common occurrences. The animals may have been "wise" to escape disturbance and thus move to the safer area of Arakhuan Range. The possibility that the animals have acclimatized themselves to some human activities also implies that more of them could be observed, thus influencing any census conducted in the area.

\section{Conservation status of animals}

Okomu National Park represents one of the last major fragments of the rain forest ecosystems of south western Nigeria (Orhierre 1992; Agbelusi et al., 2003; Greengrass 2006). Most of the encountered large mammals are regarded as endangered (EN) and vulnerable (VU) by the World Conservation Union (IUCN) standard. The forest Elephant (EN), White throated monkeys (EN), Red-cap mangabey (EN), Yellow backed duiker (EN), Putty-nose monkey (VU), Red flanked duiker (VU), while Mona monkeys and Maxwell's duiker are at lower risk. The conservation status of kususimance mangoose is indeterminate.

\section{Conclusion}

Arakuan range in the Okomu National Park offers spectacular opportunity to boost the tourism potential of the park with the assurance of sightings of about 12 large mammalian species directly. The tourist facilities (tracks, trails, and accommodation) (Plate 8) already developed in the range provides a wide range of complimentary destination that could be harnessed for ecotourism development. Since nature conservation is a very important land use form, it is important to develop their bases for profit-oriented management so that they can withstand the economy and political treat that challenge their existence. This is one of the ways to guarantee their sustainable utilization for a long time. There is the need to enforce strict protection of these animals in the range in order to prevent the occurrences of the situation as in other ranges. 


\section{References}

Afolayan, T. A., Agbelusi, E. A. and Ogunjemite, B. G. (2004). Resources Conservation and Your Future. In: Egunjobi, O. A., Kayode, J., Faluyi, M. A.., Mukolu, A. and Afolabi, O. (eds). Enviromental degradation, reclamation, conservation and pollution control. The Nigerian National Commission for UNESCO.

Agbelusi E. A., (1994). Wildlife Conservation in Ondo States, Nigeria, Nigerian. Field 59, 73 - 83.

Agbelusi E. A., Ogunjemite B.G., Koyenikan, I. O. and Okeyoyin O. A. (2003). The primate fauna and the distribution of chimpanzees of Okomu National Park, Edo State, Nigeria._Journal Tropical Forest Resource Management 19, 161-170.

Agbelusi, E. A., Ogunjemite, B. G. and Afolayan, T. A. (1999). A survey of the primates of Ondo and Ekiti States. Journal of Tropical Ethnoforestry 2(1), 100-106.

Agbelusi, E.A. and Afoloyan, T.A. (1991). Mammalian species of Ifon Game Reserve. Journal of Environmental Conservation. 19 (1): 74-76

Akinyemi, A. F. and Odutan, O. O. (2004). An evaluation of the effect of conservation legislation on wildlife offences in the Yankari National Park, Bauchi, Bauchi State. Nigerian Journal of Forestry 34 (1), 28-35

American Sub-committee on Conservation of natural populations, (1981). Techniques for the study of primate population ecology, Washington. National Academy Press.

Child, B. (2000). Making wildlife pay: Converting wildlife comparative advantage into real incentives for having wildlife in African Savannas; Case studies from Zimbabwe and Zambia, in Prins, H.T., Grootenhuis, J.G and Dolan, TT (eds) Wildlife conservation by sustainable use. London. Knuwer Academic Publishers.

Dunn, A. (1999). Gashaka / Gumni National Park: A Guide Book, NCF, NNP and WWF 80 pp.

Eisenberg, J. F. (1990). Mammals of neotropics, Vol. 1. The northern Neotropic. Chicago. University of Chicago Press.

Emmons, L. H. (1990). Neotropical rainforest mammals. A field Guide, Second edition. Chicago. University of Chicago Press.
Greengrass, E. J. (2006). A survey of Chimpanzees in South-West Nigeria. NCF-WCS Biodiversity Research Programme. 51 pp.

Ikhuoria I.A. (1993). Vegetation and land-use Changes in a Rainforest Ecosystem. Nigerian Journal of Remote Sensing 1, 73-82.

Koyenikan, I. O. (2004). Impact of human activities on the primates of Okomu National Park, Edo State, Nigeria. Master of Agricultural Technology Thesis, Federal University of Technology, Akure

Mandujano, S. and Gallina, S. (1995). Comparison of deer censusing methods in tropical dry forest. Wildlife Society Bulletin. 23, 180-186.

Marguba L. B. (1996). The Margazine of the Nigeria National Parks, Vol. 1 No 2. July, 1996.

Mendoza, M. and Palmqvist, P. (2006). Characterizing adaptive morphological patterns related to habitat use and body mass in Bovidae. Acta Zoological Sinica 52 (6), 971-987

Nigerian Conservation Foundation (1998). Management Plan for the take of proposed Okomu National Park.

Naughton - Trevee, L (1998) Predicting patterns of crop damage by wildlife around Kibale National Park Uganda. Conservation Biology 12,156-168

Newmark, W. D., Manyanza, D. N., Gamassa, D. G. M. and Sariko, H (1994). The conflict between wildlife and local people living adjacent to protected area in Tanzania.Human density as predictor. Conservation Biology 9, 249 - 255

Oates, J. F., Ikemeh, R. A., Ogunsesan, A. and Bergl, R. A. (2008). A survey of rainforests in Ogun, Ondo and Osun States in Southwestern Nigeria to assess options for sustainable conservation. NCF Lagos. 42pp.

Oates, J.F. (1995). The dangers of Conservation by Rural Development -a case study from the Forest of Nigeria. ORYX vol. 129 No. 2 pg. 115-122.

ODA/WWF/CEC (1990). Overseas Development Administration, World wide Fund for Nature and Commission for the European Communities: Cross river National Park, Okwangwo Division, Plan for the park and its support zone, 108pg

Odewumi, S.O. (2004). Assessment of the ecotourism potentials of Ebomi Lake, Ondo and Ekiti State, Nigeria. Master of Agricultural Technology Thesis. Federal University of Technology, Akure. 93pp 
Oduwaiye, E.A., Oyeleye, B. and Oguntala, A. B. (2002). Species diversity and potentiality for forest regeneration in Okomu Sample plot In Abu J. E., Oni, P. I. and Popoola, L. (eds) Forestry and Challenges of sustainable livelihood. Proceedings of the $28^{\text {th }}$ Annual Conference of forestry Association of Nigeria. Akure 2002.

Ogunjemite, B. G., Ajayi, B. and Agbelusi, E. A. (2007). Habitat structure of chimpanzee communities in Nigeria: a comparison of sites. Acta Zoological Sinica 53(4), 579 - 588.
Onadeko, S. A. (2004). Home on the range: Crises, consequences and consolations. Inaugural Lecture Series. University of Agriculture, Abeokuta, Nigeria pp86.

Orhierre, S. S. (1992). Okomu Wildlife Sanctuary: Okomu Forest Reserve, Edo State. Nigerian Field 57, 91-102.

Tutins, C. E. G. and Fernandez, M. (1984). Nationwide census of Gorilla and Chimpanzee population in Gabon. American-Journal of Primatol. 6: 313 - 336.

Table 1: Species composition of censured large mammals of Arakhuan Range, Okomu National Park

\begin{tabular}{|c|c|c|c|}
\hline & Family & Species & Common name \\
\hline \multirow[t]{4}{*}{ Monkeys } & Cercopithecidae & Cercocebus torquatus & Red-capped \\
\hline & & Cercopithecus erythrogaster & White-throated \\
\hline & & Cercopithecus nictitans & Putty-nosed \\
\hline & & Cercopithecus mona & Mona monkey \\
\hline \multirow[t]{3}{*}{ Duikers } & Cephalophinae & Cephalophus maxwelli & Maxwell's duiker \\
\hline & & Cephalophus sylvicultor & Yellow-backed duiker \\
\hline & & Cephalophus rufilatus & Red-flanked duiker \\
\hline Mangoose & Viverridae & Crossarchus obscures & Kucusimance mangoose \\
\hline
\end{tabular}

Source: Field survey 2008/2009

TABLE 2: Sightings of large mammals of Arakhuan Range in Okomu National Park

\begin{tabular}{llllll}
\hline Animal Species & $\begin{array}{l}\text { Morning } \\
\text { sightings }\end{array}$ & $\begin{array}{l}\text { Evening } \\
\text { sightings }\end{array}$ & $\begin{array}{l}\text { Total no of } \\
\text { Sightings }\end{array}$ & Sightings/km & $\begin{array}{l}\text { Length of } \\
\text { transect cover } \\
\text { for } 1 \\
\text { sighting/ km }\end{array}$ \\
\hline Mona monkey & 23 & 14 & 37 & 0.22 & 4.5 \\
White throated monkey & 12 & 7 & 18 & 0.11 & 9.3 \\
Redcapped mangabey & 8 & 8 & 16 & 0.10 & 10.4 \\
Putty nosed monkey & 2 & 1 & 3 & 0.02 & 41.7 \\
Maxwell duiker & 14 & 10 & 25 & 0.15 & 6.67 \\
Redflanked duiker & 17 & 13 & 28 & 0.17 & 5.96 \\
Yellow backed duiker & 2 & 1 & 3 & 0.02 & 55.6 \\
Kucusimance mangoose & 7 & 8 & 15 & 0.09 & 55.6 \\
\hline
\end{tabular}

Source: Field survey 2008/2009 
Table 3: Animals distribution based on the transects used

\begin{tabular}{|c|c|c|c|c|c|c|c|c|}
\hline & Transect A & & Transect B & & Transect $\mathrm{C}$ & & Transect D & \\
\hline Animal species & No of Sightings & $\begin{array}{l}\text { Sightings/ } \\
\text { km }\end{array}$ & $\begin{array}{l}\text { No of } \\
\text { Sightings }\end{array}$ & $\begin{array}{l}\text { Sightings/ } \\
\mathrm{km}\end{array}$ & $\begin{array}{l}\text { No of } \\
\text { Sightings }\end{array}$ & $\begin{array}{l}\text { Sightings } \\
\mathrm{km}\end{array}$ & $\begin{array}{l}\text { No of } \\
\text { Sightings }\end{array}$ & $\begin{array}{l}\text { Sightings/ } \\
\mathrm{km}\end{array}$ \\
\hline Mona monkey & 16 & 0.40 & 10 & 0.28 & 6 & 0.13 & 5 & 0.12 \\
\hline White throated monkey & 12 & 0.30 & 2 & 0.06 & 2 & 0.04 & 2 & 0.05 \\
\hline Red-capped mangabey & 9 & 0.23 & 3 & 0.08 & 4 & 0.08 & - & - \\
\hline Putty nosed monkey & 3 & 0.08 & - & - & - & - & - & - \\
\hline Maxwell duiker & 13 & 0.33 & 2 & 0.06 & 7 & 0.15 & 3 & 0.07 \\
\hline Red-flanked duiker & 17 & 0.43 & 7 & 0.19 & 4 & 0.08 & - & - \\
\hline Yellow-backed duiker & - & - & - & - & 3 & 0.06 & - & - \\
\hline Kucusimance mangoose & 9 & 0.23 & - & - & 6 & 0.13 & - & - \\
\hline
\end{tabular}

Source: Field survey 2008/2009 
TABLE 4: Estimated populations of censured large mammals of Arakhuan Range

\begin{tabular}{|c|c|c|c|c|}
\hline & Density & $\begin{array}{l}\text { Estimated } \\
\text { population } \\
\text { (troop) }\end{array}$ & $\begin{array}{l}\text { Average } \\
\text { Troop size }\end{array}$ & $\begin{array}{l}\text { Estimated } \\
\text { population } \\
\text { (individual) }\end{array}$ \\
\hline Mona monkey & $4.47 \pm 1.24$ & $240.18 \pm 66.49$ & 7 & $1441.05 \pm 398.96$ \\
\hline $\begin{array}{l}\text { White throated } \\
\text { monkey }\end{array}$ & $2.66 \pm 1.52$ & $142.93 \pm 81.55$ & 6 & $857.2 \pm 489.45$ \\
\hline $\begin{array}{l}\text { Red-capped } \\
\text { mangabey }\end{array}$ & $2.15 \pm 0.88$ & $115.7 \pm 47.36$ & 3 & $347.3 \pm 142.29$ \\
\hline $\begin{array}{l}\text { Putty nosed } \\
\text { monkey }\end{array}$ & $2.40 \pm 1.50$ & $20.7 \pm 12.08$ & 13 & $128.84 \pm 81.49$ \\
\hline Maxwell duiker & $20.54 \pm 5.44$ & - & & $1104 \pm 292.65$ \\
\hline Red flanked duiker & $36.66 \pm 7.68$ & - & & $1970.93 \pm 412.93$ \\
\hline $\begin{array}{l}\text { Yellow backed } \\
\text { duiker }\end{array}$ & $0.17 \pm 0.36$ & - & & $9 \pm 2$ \\
\hline $\begin{array}{l}\text { Kucusimance } \\
\text { mangoose }\end{array}$ & $8.16 \pm 3.96$ & - & & $438.43 \pm 212.64$ \\
\hline
\end{tabular}

Source: Field survey 2008/2009

TABLE 5: Other large mammals observed in the range

\begin{tabular}{lcl}
\hline Species & Opportunistic sighting & Other signs observed \\
\hline $\begin{array}{l}\text { Elephant (Loxodonta africana } \\
\text { cylotis) }\end{array}$ & - & $\begin{array}{l}\text { Footprints, dung, debarking } \\
\text { and felling of trees (of }\end{array}$ \\
& & $\begin{array}{l}\text { Musanga sp, Albizia sp), } \\
\text { feeding the seed and root of } \\
\text { Tamococcus sp }\end{array}$ \\
$\begin{array}{l}\text { Bush pig(Potamochoerus } \\
\text { porcus) }\end{array}$ & 2 & Feeding sedges crabs and \\
Civet cat(Viverra civeta) & & snails, footprints \\
$\begin{array}{l}\text { Forest buffalo (Syncerus } \\
\text { caffer) }\end{array}$ & - & Footprints \\
\hline
\end{tabular}

Source: Field survey 2008/2009 


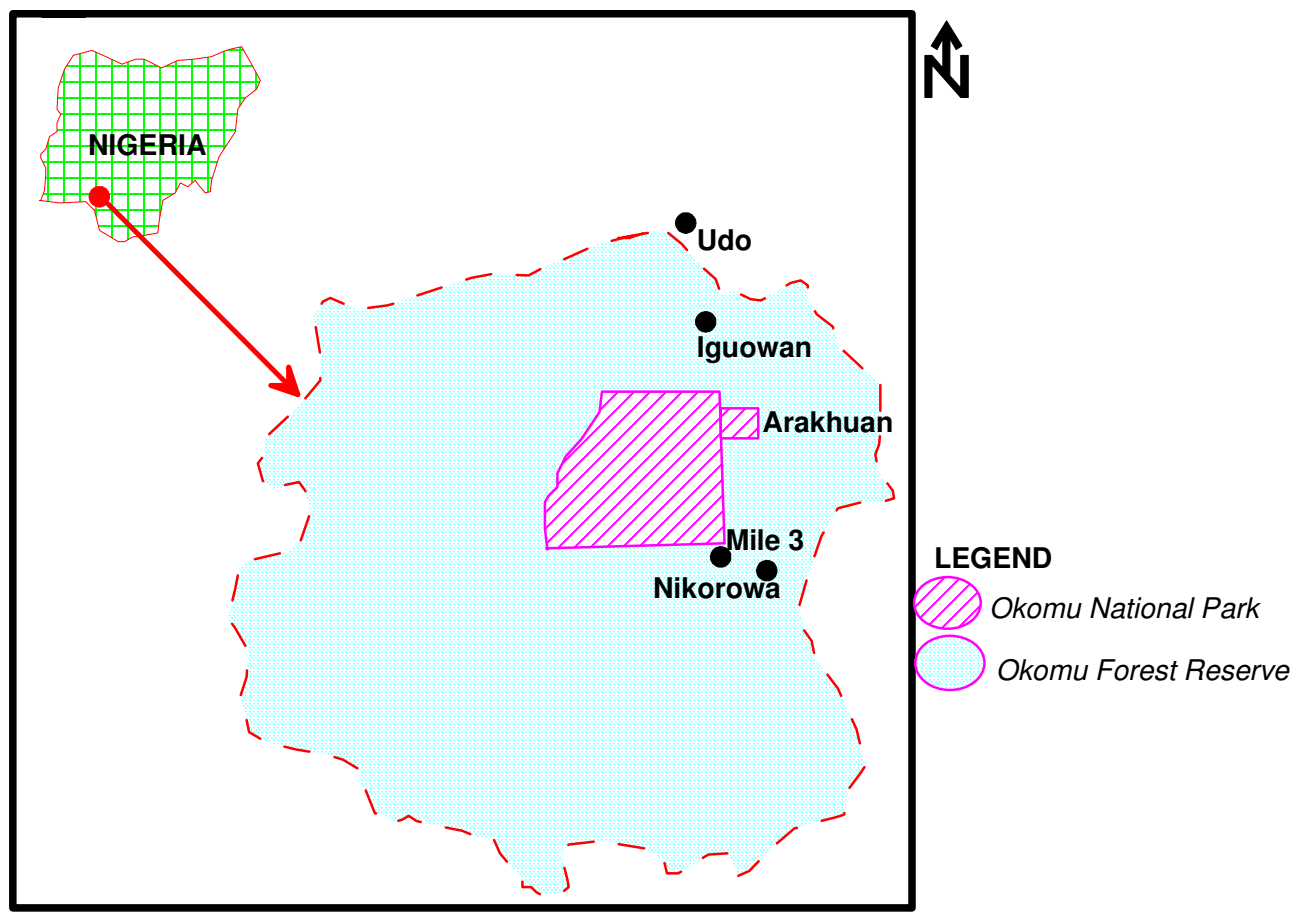

Fig. 1 Location Map of Okomu National Park

(Source: Nigeria Conservation Foundation, 1998.)

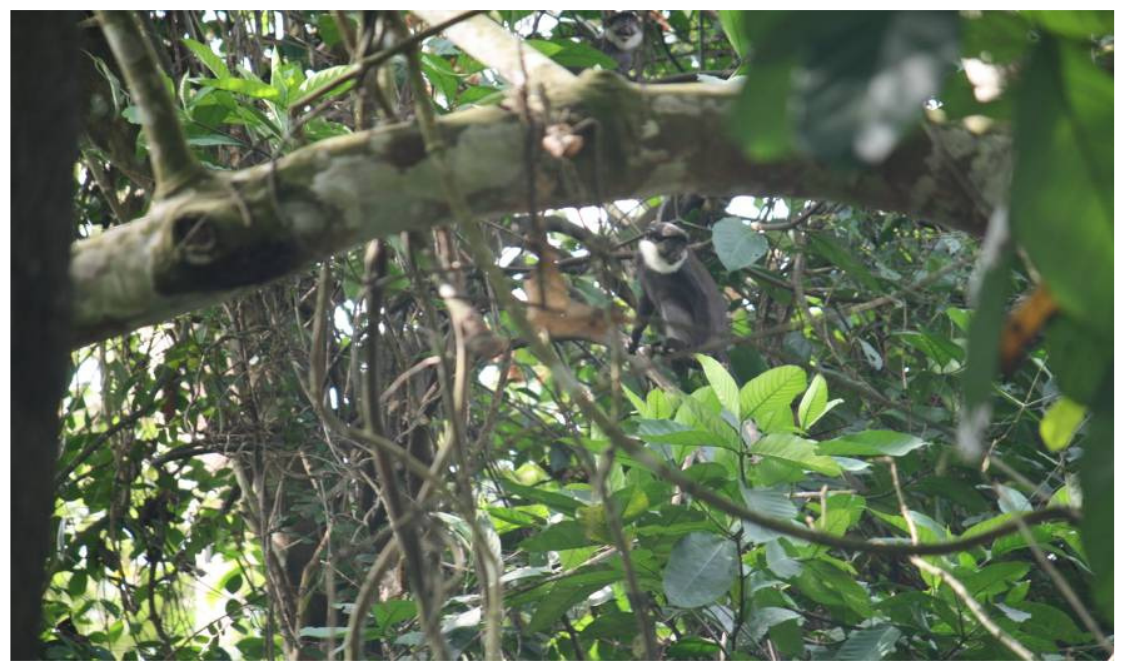

Plate 1: The white throated monkeys in thicket forest habitat of Arakhuan Range Okomu National Park (ONP) 


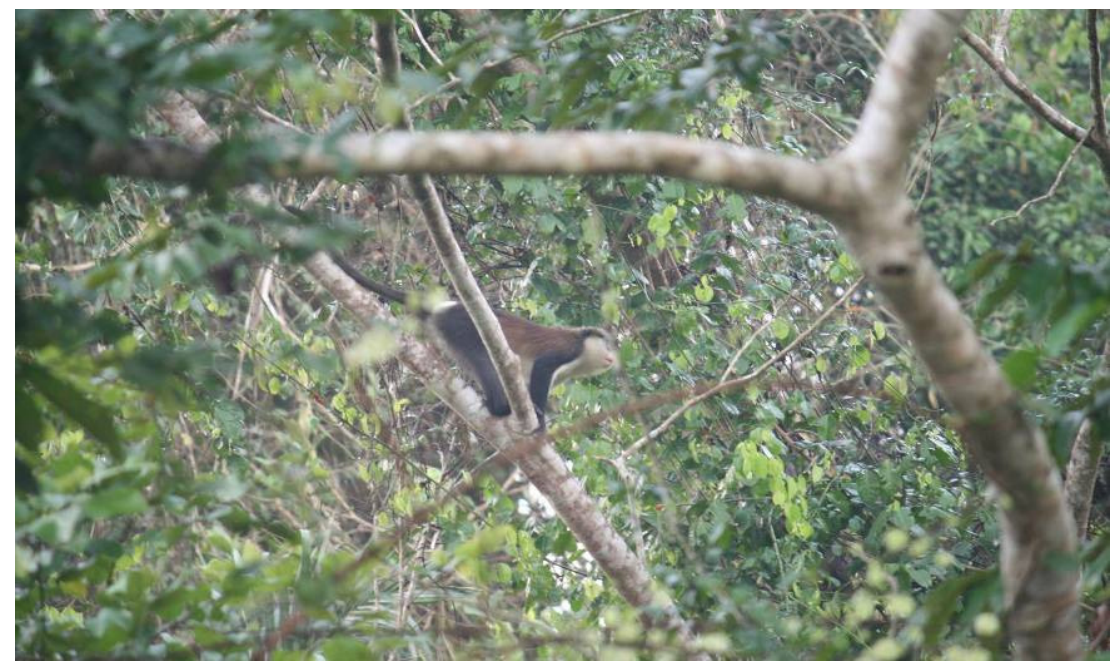

Plate 2: The mona monkey in matured forest habitat of Arakhuan Range (ONP)

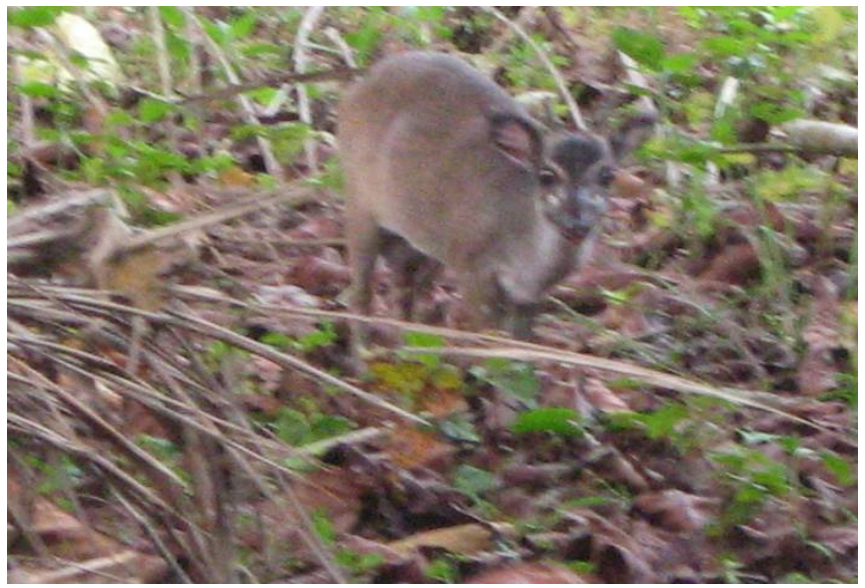

Plate 3: The maxwell's duiker along the forest margin habitat of Arakhuan Range (ONP)

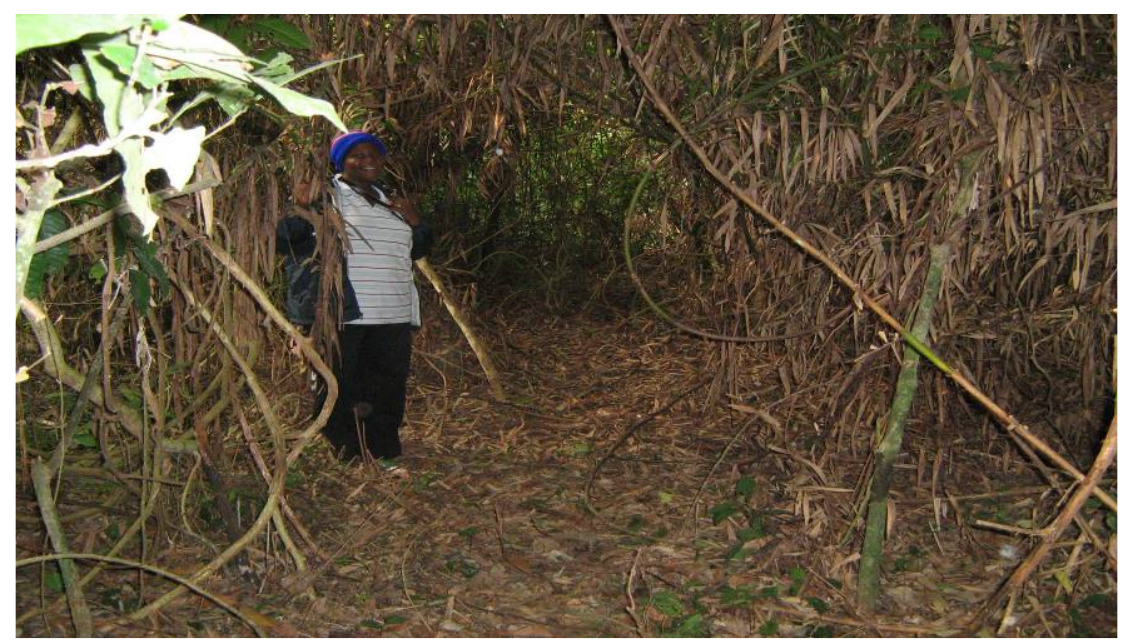

Plate 4: The elephant trail along transect A of Arakhuan Range (ONP) 


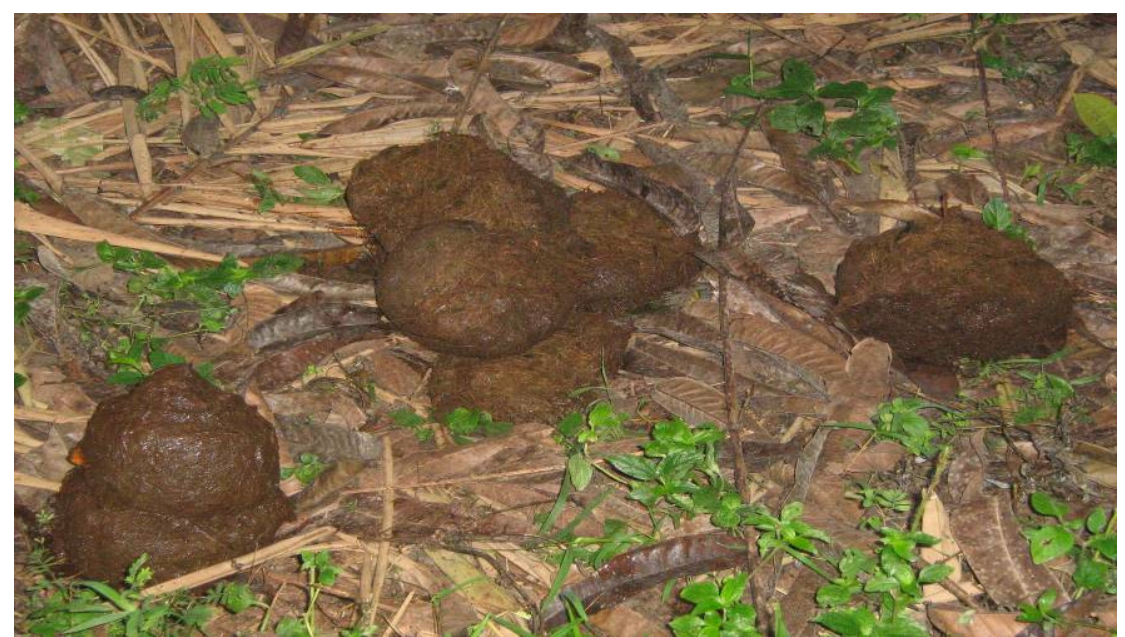

Plate 5: Fresh dung of elephant along transect $\mathrm{C}$

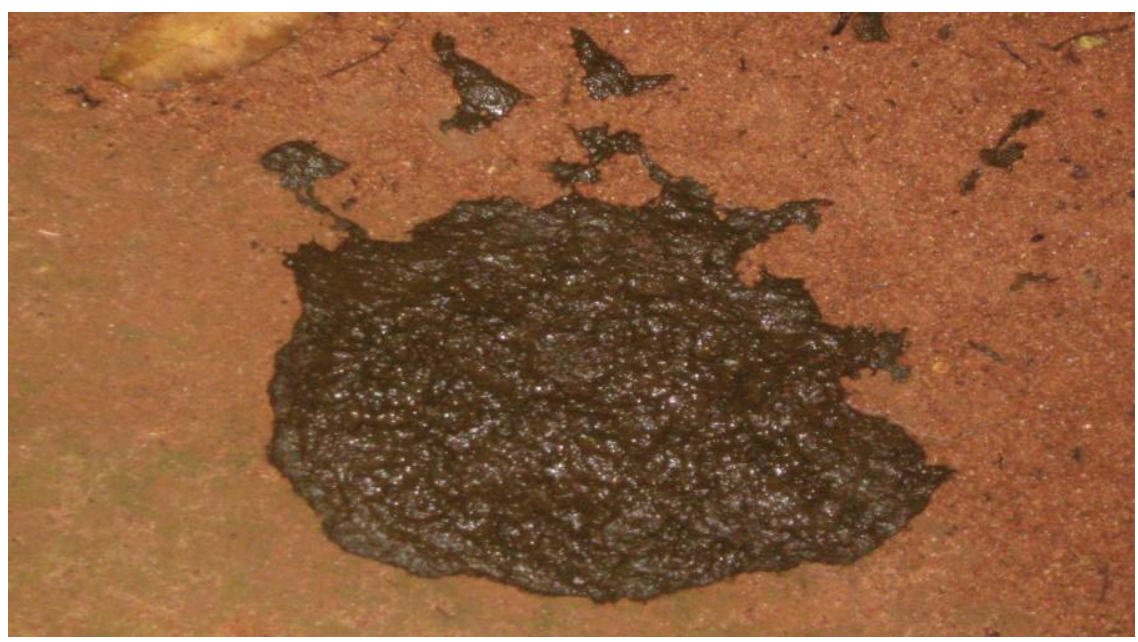

Plate 6: Fresh dung of buffalo along transect $\mathrm{C}$ 


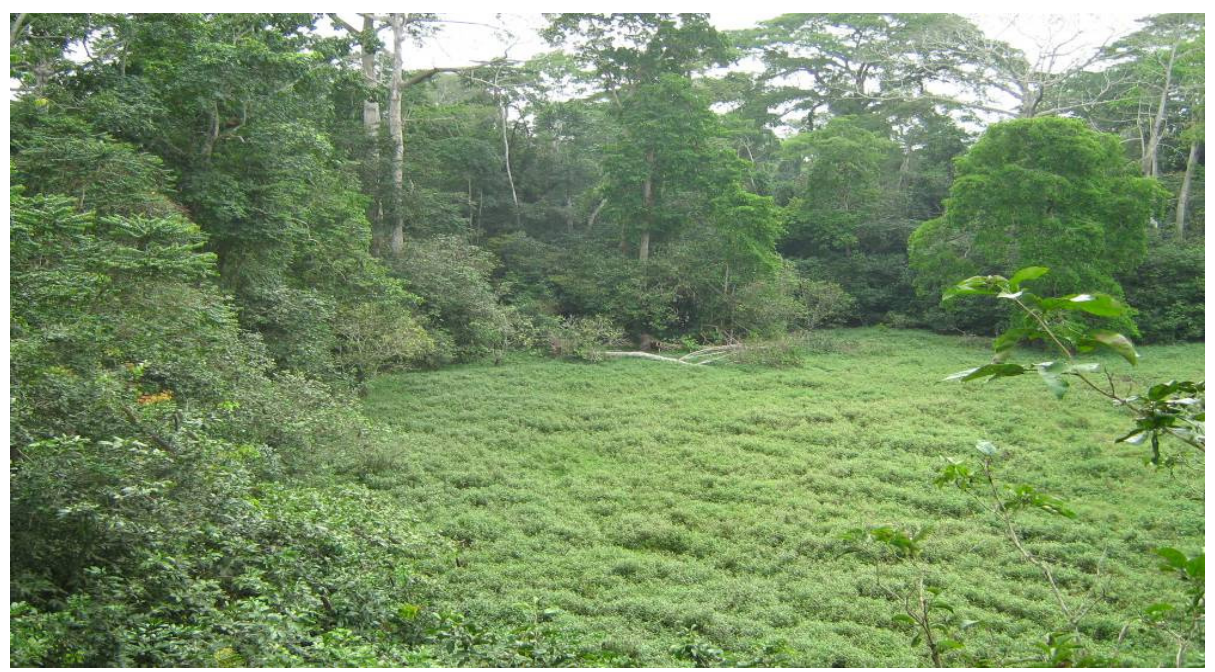

Plate 7: Forest margin along "lakes" like this supports the red river hog in Okomu National Park

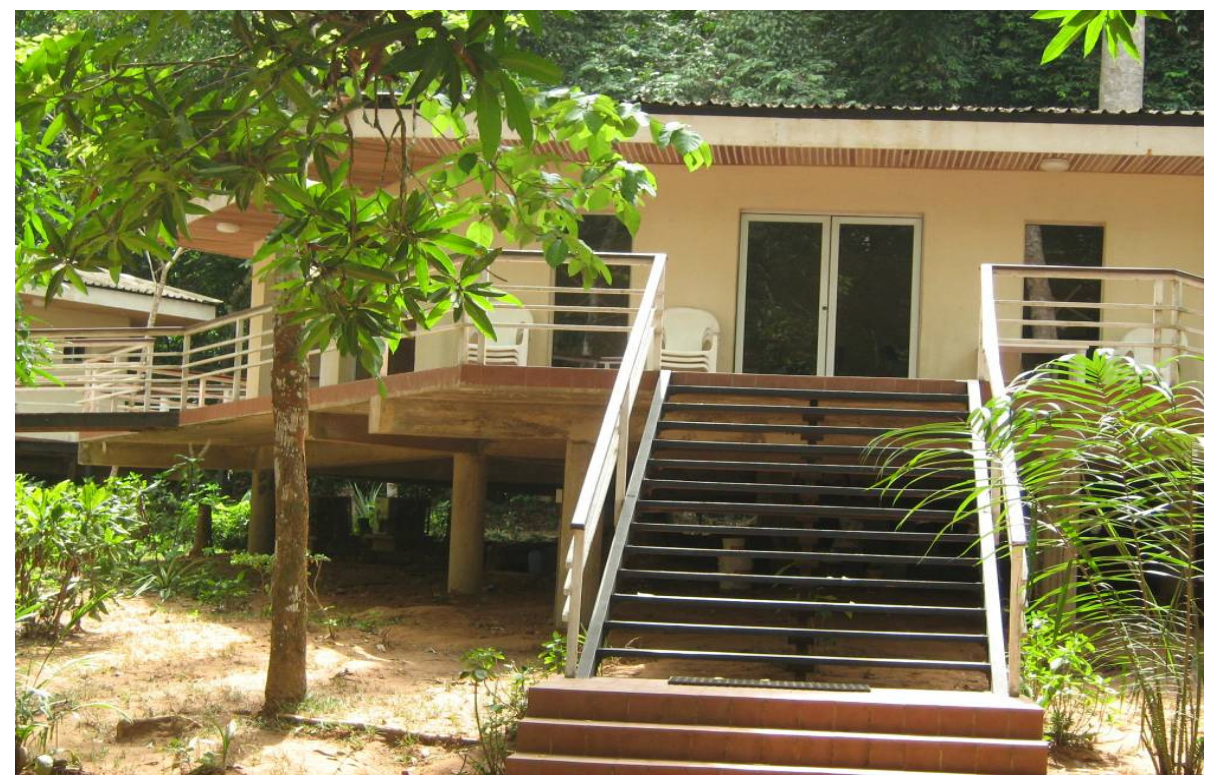

Plate 8: The executive chalets at Arakhuan Base Camp, Okomu National Park (ONP) 